\title{
Survivin Blockade Sensitizes Rhabdomyosarcoma Cells for Lysis by Fetal Acetylcholine Receptor-Redirected T Cells
}

Katja Simon-Keller, ${ }^{*}$ Annette Paschen, ${ }^{\dagger}$ Andreas A. Hombach, ${ }^{\ddagger}$ Philipp Ströbel, ${ }^{\S}$ Jean-Michel Coindre, ${ }^{\circledR}$ Stefan B. Eichmüller,

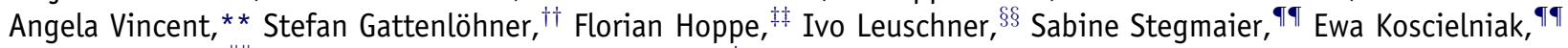
Martin Leverkus, \|\|$\|$ Dario C. Altieri, ${ }^{* * *}$ Hinrich Abken, ${ }^{\ddagger}$ and Alexander Marx ${ }^{*}$

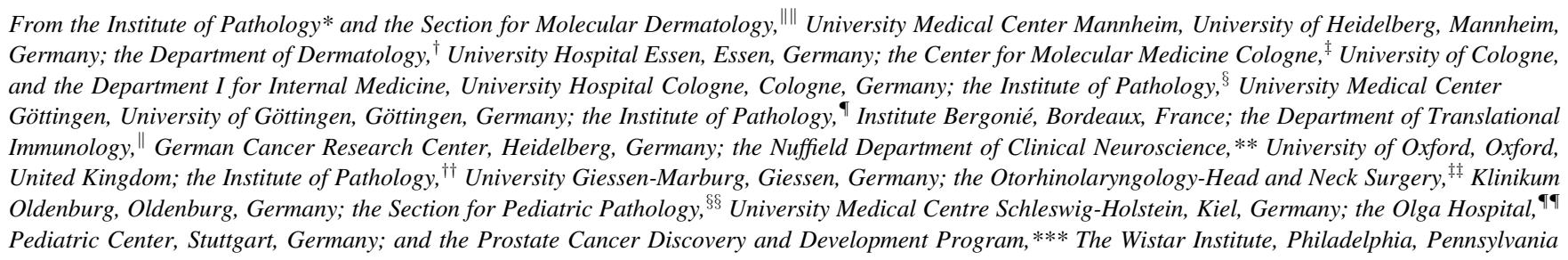

Accepted for publication

February 25, 2013.

Address correspondence to Alexander Marx, M.D., Institute of Pathology, University Medical Center Mannheim, University of Heidelberg, Theodor-Kutzer-Ufer 1-3, D-68135 Mannheim, Germany. E-mail: alexander. marx@umm.de.
Cellular immunotherapy may provide a strategy to overcome the poor prognosis of metastatic and recurrent rhabdomyosarcoma (RMS) under the current regimen of polychemotherapy. Because little is known about resistance mechanisms of RMS to cytotoxic T cells, we investigated RMS cell lines and biopsy specimens for expression and function of immune costimulatory receptors and anti-apoptotic molecules by RT-PCR, Western blot analysis, IHC, and cytotoxicity assays using siRNA or transfection-modified RMS cell lines, together with engineered RMS-directed cytotoxic T cells specific for the fetal acetylcholine receptor. We found that costimulatory CD80 and CD86 were consistently absent from all RMSs tested, whereas inducible T-cell co-stimulator ligand (ICOS-L; alias B7H2) was expressed by a subset of RMSs and was inducible by tumor necrosis factor $\alpha$ in two of five RMS cell lines. Anti-apoptotic survivin, along with other inhibitor of apoptosis (IAP) family members (cIAP1, cIAP2, and X-linked inhibitor of apoptosis protein), was overexpressed by RMS cell lines and biopsy specimens. Down-regulation of survivin by siRNA or pharmacologically in RMS cells increased their susceptibility toward a T-cell attack, whereas induction of ICOS-L did not. Treatment of RMS-bearing $\mathrm{Rag}^{-/-}$mice with fetal acetylcholine receptor-specific chimeric T cells delayed xenograft growth; however, this happened without definitive tumor eradication. Combined blockade of survivin and application of chimeric T cells in vivo suppressed tumor proliferation during survivin inhibition. In conclusion, survivin blockade provides a strategy to sensitize RMS cells for T-cellbased therapy. (Am J Pathol 2013, 182: 2121-2131; http://dx.doi.org/10.1016/j.ajpath.2013.02.017)
Rhabdomyosarcoma (RMS) is the most common pediatric soft tissue malignancy. Although the cure rates increased from $25 \%$ in 1970 to $70 \%$ in 1990 , based on multimodal approaches with chemotherapy, surgery, and irradiation, no further improvement has been achieved during the past 20 years. In addition, patients with primary metastatic and recurrent disease, particularly those with alveolar RMS, have an extremely poor prognosis ( $<20 \%$ cure rate) ${ }^{1,2}$ Therefore, new therapeutic approaches are urgently needed. Immunotherapies provide alternative approaches, the most promising of which are vaccination toward tumor antigens ${ }^{3,4}$ and adoptive transfer of redirected cytotoxic $\mathrm{T}$ lymphocytes with engineered specificity provided by a chimeric antigen receptor (CAR). ${ }^{5}$

\footnotetext{
Supported by Tumorzentrum Heidelberg-Mannheim grant 781023 (K.S.-K., A.P., and A.M.), Deutsche Krebshilfe grant 109891 (A.M. and M.L.), Helmholtz Alliance on Immunotherapy of Cancer (A.P.), Wilhelm-Sander-Stiftung grants 2008.072.1 (M.L.), and Deutsche Forschungsgemeinschaft grants Le 953/5-1 and Le 953/6-1. Work in the Abken laboratory was supported by Deutsche Krebshilfe grant 109925 and Deutsche Forschungsgemeinschaft, Bonn, grant AB58/9-1. Work in the Koscielniak laboratory was supported by Adolph Messer Stiftung, Frankfurt, and Foerderverein Krebskranke Kinder e. V., Stuttgart.
} 
Vaccination against RMS is tested in clinical trials using RMS-specific neopeptide or peptides from broadly expressed tumor antigens, such as WT1. ${ }^{3,4}$ Complex vaccination protocols are required to achieve efficacy, including the use of autologous $\mathrm{T}$ cells, peptide-pulsed dendritic cells, and cytokines to maintain survival of RMS-specific T cells in vivo. ${ }^{3}$ A variety of factors, however, affect the vaccination efficiency, including the expression levels of major histocompatibility complex classes I and II and costimulatory and co-inhibitory molecules on tumor cells. ${ }^{6-8}$ The frequency of natural precursors of tumor-reactive $\mathrm{T}$ cells, moreover, varies widely in different patients and may be too low to achieve therapeutic efficacy. ${ }^{6}$

An alternative strategy is the adoptive transfer of chimeric $\mathrm{T}$ cells that are genetically engineered with a CAR with predefined specificity. Chimeric T cells are redirected in an antibody-based, major histocompatibility complexindependent manner toward predefined cell surface targets. Because CD80 costimulation is indispensable for full T-cell activation, amplification, and long-term survival, the CD28 signaling domain was added to the $\mathrm{CD} 3 \zeta$ signal in the $\mathrm{CAR}$ to sustain the CAR-redirected T-cell response in the longterm. ${ }^{9-11}$ CAR-redirected $\mathrm{T}$ cells are explored in clinical trials, with significant success. ${ }^{12}$ The CAR used in the current study is directed against the fetal acetylcholine receptor (fAChR) ${ }^{13-16}$ that is suitable for targeting RMS because it is expressed on various RMS subtypes but not on postnatal muscle or other relevant healthy tissue cells. ${ }^{15,17}$

The cytolytic efficacy of adoptively transferred cytotoxic $\mathrm{T}$ cells can be affected by anti-apoptotic protection of the target cell; granzyme-mediated mitochondrial release of proapoptotic smac is blocked in some tumor cells, protecting from cell death by cytotoxic T lymphocytes. ${ }^{18}$ Similarly, overexpression of X-linked inhibitor of apoptosis protein (XIAP) can block execution of T-cell-mediated cytolysis, which can be overcome by phorbol-12-myristate-13-acetateinduced protein 1 (PMAIP1)-mediated enhancement of mitochondrial second mitochondria-derived activator of caspase release. ${ }^{19}$ Survivin, another IAP family member, stabilizes high XIAP levels in malignant cells, thereby contributing to apoptosis resistance. ${ }^{20,21}$ Consistently, we observed that lysis of RMS cells by RMS-directed cytotoxic $\mathrm{T}$ cells was unexpectedly poor, ${ }^{22}$ suggesting that some resistance mechanisms may protect RMS cells.

Herein, we report that RMS resistance to a cytolytic T-cell attack is the result of at least two mechanisms: lack of costimulatory molecules required for sustained T-cell activation and overexpression of anti-apoptotic molecules. Among these, survivin became crucial because survivin repression by siRNA or blockade by pharmacological interference substantially increased the susceptibility of RMS cells to a cytolytic T-cell attack, implying survivin as a key target to improve RMS sensitivity for adoptive immunotherapy.

\section{Materials and Methods}

\section{Biopsy Specimens}

RMS biopsy specimens from three patients primarily seen at the Mannheim Sarcoma Center (Mannheim, Germany) (Ma5, Ma13, and Ma15), and 20 RNA samples from the Cooperative Weichteilsarkom Studiengruppe (CWS) tissue bank (Stuttgart, Germany) (S1 to S20) were studied (Table 1). The histopathological features of all cases were centrally reviewed by Prof. I. Leuschner (Pediatric Tumor Registry, Kiel, Germany), who also provided muscle tissue from five other (anonymous) patients. All patients were treated according to CWS protocols (CWS-96 or CWS-2002P). All studies were approved by the appropriate ethics and review committees [approval 158/2009/ b02; University of Tübingen, Tübingen, Germany; April 2, 2009) and 2012-257N-MA (University of Heidelberg, University Medical Centre Mannheim, Mannheim; April 12, 2012)]. Written informed consent, according to the Declaration of Helsinki, was obtained from all patients or their legal guardians, depending on the patients' age. All cases were studied by RT-PCR for fAChR expression ${ }^{14}$ and for PAXFKHR fusion transcript status by the Molecular Biology Laboratory at Olga Hospital (Stuttgart). ${ }^{24}$

\section{Cells}

The 293T human embryonic kidney cells expressing the large SV40 antigen, HeLa, and HT29 cells were cultured in Dulbecco's modified Eagle's medium with $10 \%(\mathrm{v} / \mathrm{v})$ fetal calf serum. The alveolar RMS cell lines CRL2061, RH41 (all Pax3-FKHR-translocation positive), and FLOH1 (translocation negative) were cultivated in RPMI 1640 medium with $10 \%(\mathrm{v} / \mathrm{v})$ fetal calf serum. The embryonal RMS cell lines RD6 and TE671, which is a subline of RD6, ${ }^{25}$ were maintained in Dulbecco's modified Eagle's medium with $10 \%(\mathrm{v} / \mathrm{v})$ fetal calf serum.

Table 1 RMS Biopsy Specimens Used in This Study

\begin{tabular}{lll}
\hline Variable & Embryonal RMS $(n=13)$ & Alveolar RMS $(n=10)$ \\
\hline Age (years) & $4.27 \pm 3.0$ & $12.3 \pm 3.4$ \\
Female/male ratio & $6: 7$ & $6: 3 ; \mathrm{NK}, n=1$ \\
Tumor size $(\mathrm{cm})$ & $\leq 5, n=2 ;>5, n=9 ; \mathrm{NK}, n=2$ & $\leq 5, n=1 ;>5, n=8 ; \mathrm{NK}, n=1$ \\
Tumor stage & $\mathrm{I}, n=1 ; \mathrm{II}, n=3 ; \mathrm{III}, n=5 ; \mathrm{IV}, n=3 ; \mathrm{NK}, n=1$ & $\mathrm{III}, n=3 ; \mathrm{IV}, n=7$ \\
Tumor localization & $\mathrm{EXT}, n=1 ; \mathrm{OTH}, n=6 ; \mathrm{PM}, n=1 ; \mathrm{NBP}, n=1 ; \mathrm{BP}, n=1 ; \mathrm{NK}, n=3$ & $\mathrm{EXT}, n=4 ; 0 \mathrm{TH}, n=3 ; \mathrm{PM}, n=3$ \\
\hline
\end{tabular}

BP, bladder/prostate; EXT, extremities; NBP, genitourinary tract (not bladder/prostate); NK, not known (tumor stage as previously given ${ }^{1}$ ); 0TH, other sites; $\mathrm{PM}$, parameningeal. ${ }^{23}$ 


\section{Antibodies}

The following antibodies were used: anti-CD3 (BioLegend, San Diego, CA); anti-CD28 (Becton Dickenson, Franklin Lakes, NJ); goat (fluorescein isothiocyanate)-conjugated anti-human IgG antibody (Jackson ImmunoResearch, Suffolk, UK); mouse anti-human CD3-TRI-color (CALTAG Laboratories, Burlingame, NY); mouse anti-AChR antibodies against $\alpha$ - and $\gamma$-subunit (GeneTex, Irvine, CA); rat anti-human antibodies against the $\alpha$ - (198) and $\gamma$ - (66) subunits of the AChR [a kind gift from Socrates Tzartos (Hellenic Pasteur Institute, Athens, Greece)]; phycoerythrineconjugated anti-CD80 and anti-CD86 antibodies (Becton Dickenson); fluorescein isothiocyanate-conjugated antimouse antibody (R\&D Systems, Minneapolis, MN); TRIconjugated anti-mouse antibody (CALTAG Laboratories); and phycoerythrine-conjugated donkey anti-rat antibody (Jackson ImmunoResearch). Isotype-matched or secondary antibodies of irrelevant specificities were used as staining controls. ICOS-L was obtained from Acris Antibodies (Herford, Germany). Rabbit anti-survivin and rabbit anti-XIAP antibodies were obtained from Abcam (Cambridge, MA). Horseradish peroxidase-conjugated antibody (Santa Cruz Biotechnology, Dallas, TX) was used for Western blot analyses.

\section{Generation of Chimeric Antigen Receptors}

To generate the cDNA for the fAChR-specific CAR, the DNA coding for $\mathrm{scFv} 35^{14}$ was amplified by PCR and flanked by RcaI ( $\left.5^{\prime}\right)$ and BamHI $\left(3^{\prime}\right)$ restriction sites (both italicized), respectively, using the following set of primer oligonucleotides: 5'-ATGAATTTTCAGGTGCAGATTTTCAGCTTCCTGCTAATCAGTGCCTCAGTCATAATGTCTAGAGTGATGACCCAGTCTCCATCCTCCC-3' (sense) and 5'-GGATCCGGAGAGACGGTGACCGTTGT-3' (antisense). The sense primer contains a mouse leader fragment (italicized) to ensure the export of the antibody fragment. Amplified scFv35 DNA was inserted into the BW432/26scFv$\mathrm{Fc}-\mathrm{CD} 28-\mathrm{CD} 3 \zeta \mathrm{CAR},{ }^{11}$ thereby replacing the scFv element. The newly generated anti-fAChR CAR was retrovirally expressed in human lymphocytes using the Bullet vector, as described. ${ }^{26}$ Briefly, lymphocytes were isolated from healthy donors and prestimulated with the agonistic anti-CD3 and antiCD28 15E8 antibodies and retrovirally transduced after 48 hours. CAR expression was monitored by flow cytometry using an anti-IgG1 antibody (Jackson ImmunoResearch), which recognizes the CAR extracellular $\mathrm{Fc}$ spacer domain and a TRI-color-conjugated anti-CD3 antibody.

\section{Real-Time PCR}

Total RNA was extracted using TRIzol reagent (Invitrogen, Carlsbad, CA). RT-PCR was performed using RevertAid H Minus First Strand cDNA Synthesis Kit (Fermentas, St Leon Roth, Germany). PCR amplification used the Step One Plus System with the following primer oligonucleotides: glyceraldehyde-3-phosphate dehydrogenase (GAPDH), 5' -TGCACCACCAACTGCTTAGC-3' (forward) and $5^{\prime}$-GGCATGGACTGTGGTCATGAG-3' (reverse); ICOS-L, 5'-CATTGGCTGCTGCATAGAGA-3' (forward) and 5'-TTTTCTCGCCGGTACTGACT-3' (reverse); survivin, 5'-GTTGCGCTTTCCTTTCTGTC- $3^{\prime}$ (forward) and $5^{\prime}$-TCTCCGCAGTTTCCTCAAAT- $3^{\prime}$ (reverse); cIAP1, $5^{\prime}$-CCAAGTGGTTTCCAAGGTGT- $3^{\prime}$ (forward) and 5'-GGTGGGTCAGCATTTTCTTC-3' (reverse); cIAP2, 5'-CTTTGCCTGTGGTGGAAAAT-3' (forward) and $5^{\prime}$-ACTTGCAAGCTGCTCAGGAT-3' (reverse); and XIAP, 5'-CGGATCTTTACTTTTGGGACA-3' (forward) and 5'-TTGCACCCTGGATACCATTT$3^{\prime}$ (reverse). The amplification products were detected with Fast SYBR Green (both from Applied Biosystems, Foster City, CA). Data were analyzed by using the REST software tool version 2.0.7 (Qiagen, Hilden, Germany). mRNA expression levels were normalized to GAPDH mRNA.

\section{Western Blot Analysis}

Cells were washed three times with ice-cold PBS and incubated 30 minutes in $2 \%$ (w/v) SDS, $60 \mathrm{mmol} / \mathrm{L}$ Tris ( $\mathrm{pH}$ 6.8 ), phosphatase, and protease inhibitor cocktail (ProteoBlock; Fermentas) on ice. Cellular debris was removed by centrifugation, and $20 \mu \mathrm{g}$ of proteins was separated by $12 \%$ $(w / v)$ SDS-polyacrylamide electrophoresis, followed by protein transfer to polyvinylidene difluoride membranes (GE Healthcare, Little Chalfont, United Kingdom). Membranes were blocked with 5\% (w/v) low-fat milk for 30 minutes, incubated with primary antibody for 2 hours at room temperature or overnight at $4{ }^{\circ} \mathrm{C}$, washed in Trisbuffered saline and $0.05 \%(\mathrm{w} / \mathrm{v})$ Tween, and incubated with the horseradish peroxidase-conjugated secondary antibody. Binding of antibodies was visualized with the electrochemiluminescence detection reagent (GE Healthcare) and documented using the Chemismart 5100 (Peqlab, Erlangen, Germany).

\section{Cytotoxicity Assay}

Specific cytotoxicity toward target cells was monitored by an MTT (thiazolyl blue tetrazolium bromide)-based colorimetric assay (Sigma-Aldrich, St. Louis, MO). CAR-engineered and nonmodified $\mathrm{T}$ cells were cocultivated in round-bottom microtiter plates with RMS and control cells at different target/effector cell ratios. After 72 hours, $20 \mu \mathrm{L}$ of $5 \mathrm{mg} / \mathrm{mL}$ MTT was added and incubated for 4 hours at $37^{\circ} \mathrm{C}$. Reduction of MTT by viable tumor cells was colorimetrically determined by OD recording at a wavelength of $560 \mathrm{~nm}$ and a reference wavelength of $670 \mathrm{~nm}$. The viability of tumor cells was calculated as the mean of three wells containing tumor cells and effector cells, and the background was calculated as the mean of three wells containing medium. The non-specific formation of formazan was determined by three wells with the same number of effector cells as in the corresponding experimental wells. The percentage cytotoxicity was calculated as follows: 
$100-$ Viability $(\%)$, with Viability $=[\mathrm{OD}$ (Experimental Wells - Corresponding Number of Effector T Cells)/OD (Tumor Cells - Medium)]. The viability of tumor cells after cocultivation with non-transduced $\mathrm{T}$ cells was set at $100 \%$.

\section{IFN- $\gamma$ ELISA}

Quantitative determination of human interferon (IFN)- $\gamma$ was performed using the IFN- $\gamma$ enzyme-linked immunosorbent assay (ELISA; MABTECH, Nacka Strand, Sweden).

\section{SiRNA}

siRNA specific for survivin (SI00299453; Qiagen) was transfected using HiPerFect, according to the reverse transfection protocol (Qiagen). After 48 hours, cells were used for cytotoxicity tests or RNA or protein extraction. Repression of survivin expression was confirmed by quantitative real-time PCR (qPCR) and Western blot analysis.

\section{Pharmacological Gene Repression and TNF $\alpha$ Treatment}

Cells were seeded at a density of $2 \times 10^{5}$ cells in 6-well plates, grown overnight, and incubated with $60 \mu \mathrm{mol} / \mathrm{L}$ celecoxib (BioVision, Mountain View, CA) for 72 hours at $37^{\circ} \mathrm{C}$. Alternatively, cells were incubated with $50 \mathrm{ng} / \mathrm{mL}$ tumor necrosis factor (TNF) $\propto$ (R\&D Systems) for 24 hours. For the in vivo applications, the survivin inhibitor, Shepherdin (SHP), was used [a kind gift from Dario C. Altieri (Wistar Institute, Philadelphia, PA)].

\section{Mouse Model}

For the in vivo mouse experiments, $\mathrm{Rag}^{-/-}$mice, aged 6 to 10 weeks, were used. Groups of four mice were used. The animals were kept under pathogen-free conditions. Animal experiments were performed according to animal ethics committee advice and were approved by the Landesamt für Natur, Umwelt und Verbraucherschutz Nordrhein-Westfalen (Köln, Germany) by 84-02.04.2011.A093. A total of $5 \times$ $10^{6}$ RD6 embryonal rhabdomyosarcoma cells per mouse were injected s.c. into the right flank. After detectable tumor growth, mice were treated once i.v. with either $1 \times 10^{7}$ second-generation chimeric $\mathrm{T}$ cells or non-transduced $\mathrm{T}$ cells as controls, respectively. Tumor growth was determined with the aid of a caliper rule. To inhibit survivin expression of RD6 tumor cells, tumor-bearing mice were treated with $50 \mathrm{mg} / \mathrm{kg}$ SHP (resolved in PBS), which was given i.p. every 2 days. Treatment was started 7 days before T-cell application and was performed for 14 days after T-cell application.

\section{Microscopy}

Microscopy was done by an Olympus (Tokyo, Japan) Bx41 microscope and analyzed by the Olympus soft imaging software, cellF version 3.3.

\section{Statistical Analysis}

For statistical analysis, an unpaired $t$-test was applied using GraphPad software version 6.0 (GraphPad Software, Inc., San Diego, CA). RT-qPCR data were analyzed using the REST Analysis Software tool. Survival analysis was done using an SAS procedure, proc phreg (SAS version 9.3, Cary, NC).

\section{Results}

RMS Cells Mostly Lack Key Costimulatory Ligands for $\mathrm{T}$ Cells in Vitro and in Vivo

T-cell activation, proliferation, and survival are modulated by costimulatory molecules on target cells. Cells of all tested RMS lines lacked the expression of CD80 and CD86, whereas ICOS-L was expressed by FLOH1, RH41, RD6, and TE671 RMS cell lines, but not by CRL2061 cells, as recorded by flow cytometry (Figure $1 \mathrm{~A}$ and data not shown). Neither CD80 nor CD86 were detected by immunostaining in any RMS biopsy specimen (fresh-frozen tissue, $n=3$; paraffin probes, $n=10$ ), whereas expression of ICOS-L ranged from negative to strong (Figure 1B).

\section{ICOS-L, But Not CD80 and CD86, Can Be Induced on RMS Cells by TNF $\alpha$}

Because low levels of costimulatory ligands can enhance T-cell activation, we asked to induce the expression of CD80, CD86, and ICOS-L on RMS cells by TNF $\alpha$ and IFN- $\gamma$, respectively. None of the RMS cell lines became positive for CD80 and CD86 at the protein or RNA level after stimulation with $\mathrm{TNF} \alpha$ or IFN- $\gamma$. By contrast, ICOS-L expression levels marginally increased in the embryonal RMS cell line, RD6, and the alveolar RMS cell line, RH41, that constitutively express ICOS-L in the presence of TNF $\alpha$, but not of IFN- $\gamma$ (Figure 1C).

\section{Cytotoxicity Is Increased by CD80-Independent CD28} Signaling, But Not by ICOS-L

Because the CD28-mediated costimulatory signal is required to prevent T-cell anergy, we generated a second-generation CAR with the combined CD28-CD3 3 endodomain, in addition to a CAR with a $\mathrm{CD} 3 \zeta$ endodomain only (Figure 2A). The CD28-CD3 $\zeta$ signaling CAR is known to provide CD28 costimulation independently of physiological CD28-CD80 engagement. ${ }^{9-11}$ The CAR-binding domain is provided by an anti-fAChR single-chain antibody; both CARs specifically recognized fAChR ${ }^{+}$RMS cells as targets. First- and second-generation CARs were expressed with similar density on the surface of $\mathrm{T}$ cells on retroviral gene transfer (Figure 2B). Specificity of killing by chimeric $\mathrm{T}$ cells was shown by their coincubation with either fAChR or mocktransfected 293T cells (Supplemental Figure S1). T cells 
A
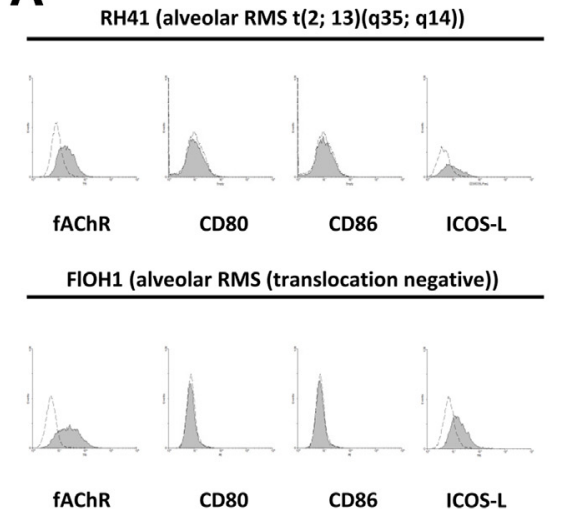

B
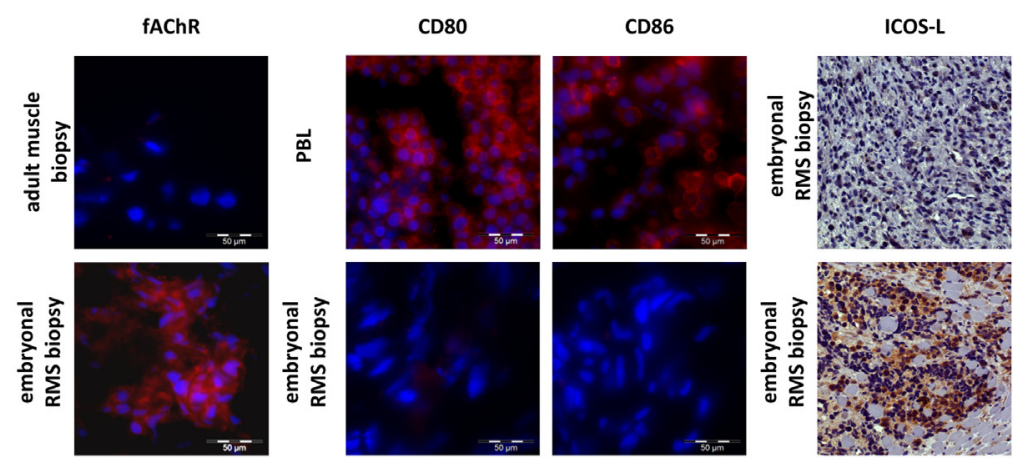

C
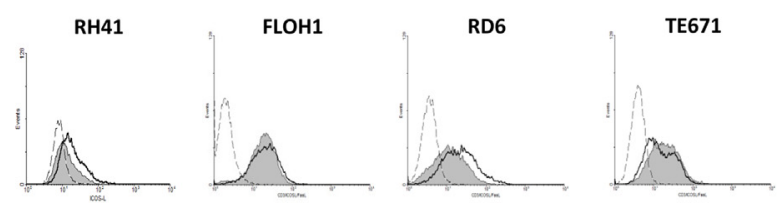

Figure 1 The RMS cells express $f A C h R$ but lack CD80 and CD86. A: Flow cytometry analysis of fAChR, CD80, CD86, and ICOS-L expression on the alveolar RMS cell lines RH41 (translocation positive) and FIOH1 (translocation negative) and embryonal RMS cell line, RD6. These cell lines are exemplarily shown; HEK 293T cells and human lymphocytes (PBLs) served as negative and positive controls, respectively. Gray histograms represent expression levels using specific antibodies; open histograms represent isotype control staining. B: Immunofluorescence analysis of fAChR expression in cells of an adult muscle biopsy specimen and of an embryonal RMS biopsy specimen from a patient (representative of six biopsy specimens investigated). Immunostaining for CD80 and CD86 in cryostat sections of RMS tissues, cytospins of freshly isolated blood lymphocytes served as positive controls, and nuclei were counterstained with DAPI. The IHC detection of ICOS-L in two RMS biopsy specimens. The cases shown are representative for the two alveolar and eight embryonal RMS biopsy specimens analyzed in this study. Original magnification: $\times 600$ (middle panels); $\times 200$ (right panels). C: Flow cytometry analysis of ICOS-L expression after treatment of RMS cell lines with TNF $\alpha$. Increased ICOS-L expression in RH41 and RD6, but not in $\mathrm{FLOH} 1$ and TE671; gray histograms represent expression levels using specific antibodies; open histograms represent isotype control staining. redirected by the $\mathrm{CD} 3 \zeta$ CAR were poorly activated on coincubation with a panel of $\mathrm{fAChR}^{+} \mathrm{RMS}$ cells indicated by low levels of IFN- $\gamma$ secretion compared with CD28-CD3 CAR T cells indicated by a stronger increase in IFN $-\gamma$ release (Figure 2C).

$\mathrm{T}$ cells redirected by the $\mathrm{CD} 28-\mathrm{CD} 3 \zeta \mathrm{CAR}$ also exhibited higher specific cytotoxicity toward various RMS cells than T cells with the CD3 $\zeta$ CAR (Figure 2D). The alveolar RMS cell lines, CRL2061, RH41, and FLOH1, were more efficiently killed by $\mathrm{T}$ cells transduced with the

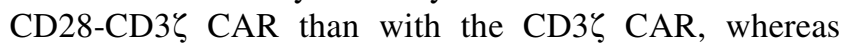
specific cytotoxicity toward the embryonal lines, RD6 and TE671, was not substantially improved. The different patterns in sensitivity toward redirected cytolysis are unlikely due to different expression levels of the targeted antigen because fAChR is expressed at nearly similar levels by those cells (Figure 1A). Treatment of target cells with TNF $\alpha$, which induced ICOS-L expression on RMS cells, did not improve CAR-redirected killing by engineered $\mathrm{T}$ cells (data not shown). Therefore, we hypothesized that RMS cells harbor an intrinsic resistance to T-cell-mediated apoptosis.

\section{RMS Cells Overexpress IAP Molecules}

Members of the IAP gene family, particularly X-linked IAP (XIAP), affect both extrinsic and intrinsic apoptotic pathways. Therefore, we recorded expression of survivin and XIAP in RMS cells by using Western blot analyses. Survivin and XIAP were overexpressed in all tested RMS cell lines (Figure 3A). Elevated survivin and XIAP expression were also detected at the mRNA level (Figure 3B). Sensitivity toward CAR T-cell-mediated cytolysis correlated with the levels of survivin. RMS cell lines that were highly resistant toward redirected T-cell killing showed higher levels of survivin protein than the less resistant cell lines (Figure 3C).

To validate the data based on the analysis of established cell lines, RMS (Table 1) and healthy muscle biopsy specimens were studied by RT-qPCR and Western blot analysis with respect to XIAP and survivin expression. All 10 alveolar and 10 embryonal RMS samples showed significantly augmented survivin mRNA expression levels compared with healthy muscle. XIAP was slightly overexpressed in 19 of 20 cases (Figure 3E). Western blot analysis 

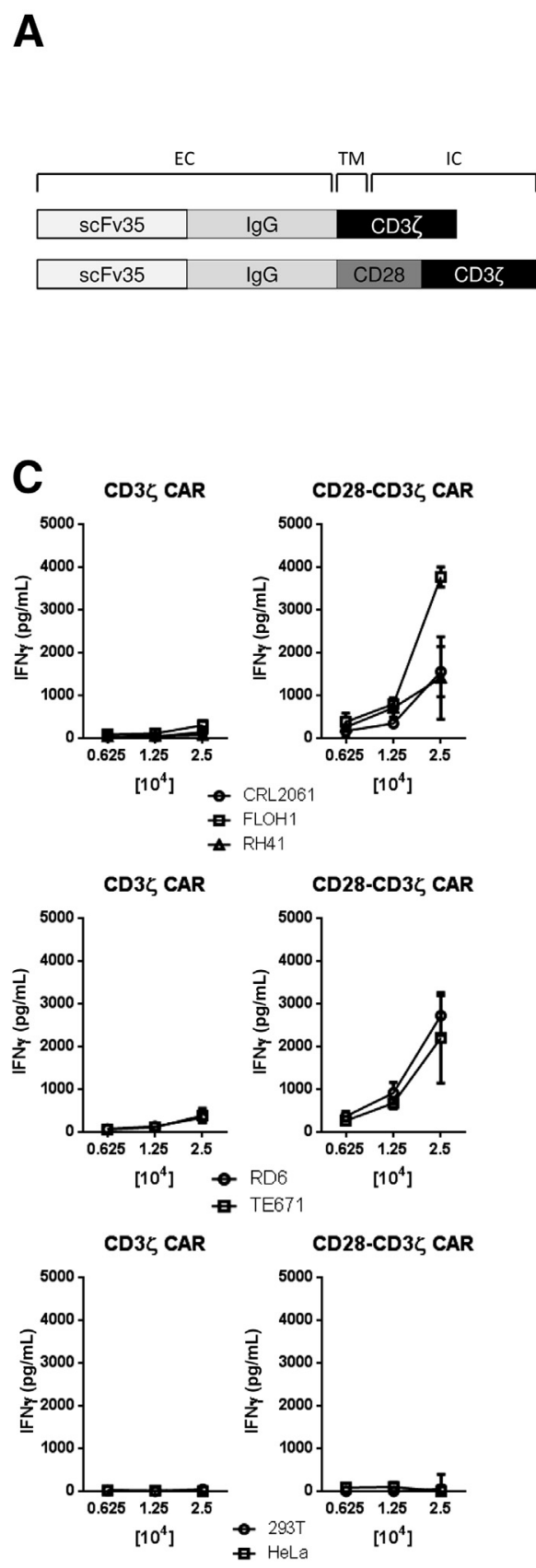
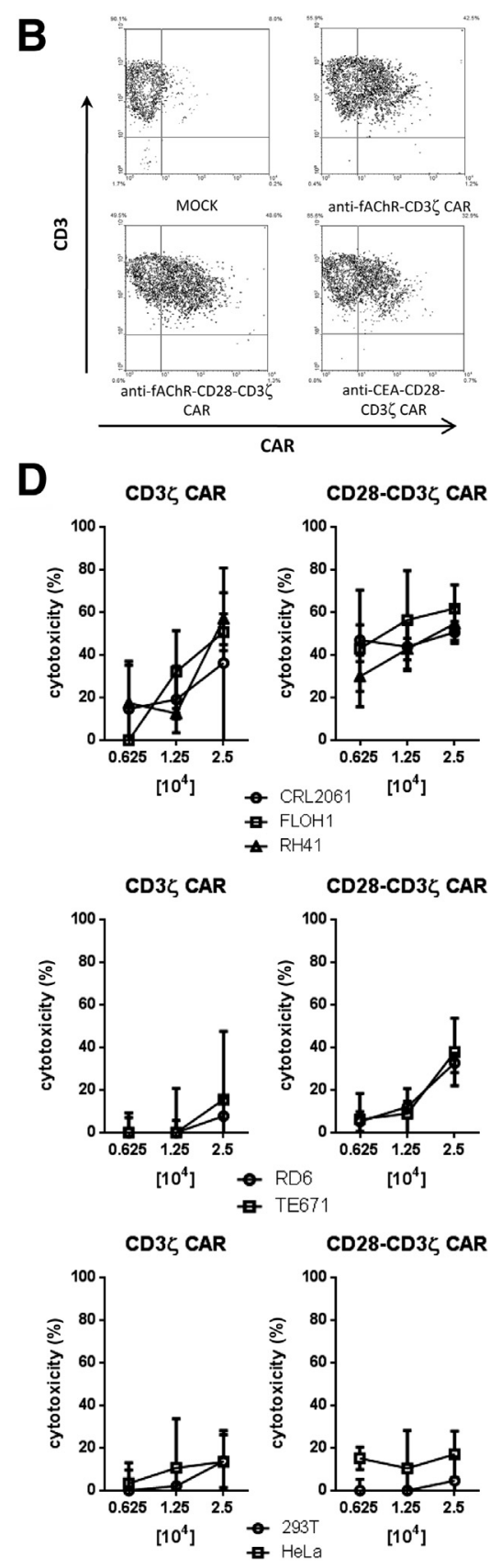

Figure 2 T cells are specifically redirected toward $\mathrm{fAChR}^{+}$RMS cells. A: Design of the $\mathrm{CD} 3 \zeta$ and $\mathrm{CD} 28-\mathrm{CD} 3 \zeta$ signaling CAR used in this study. scFv35, fAChR-specific binding domain; IgG, IgG1 $\mathrm{CH} 2 \mathrm{CH} 3$ constant and hinge region; $\mathrm{CD}_{3} \zeta$ and CD28, transmembrane (TM) and intracellular (IC) signaling domains; EC, extracellular domain. B: CAR expression by $T$ cells was recorded by flow cytometry by staining for CD3 to identify $T$ cells and for IgG, which detects the extracellular spacer domain of the respective CAR. Unmod. T cells, unmodified T cells without CAR. An anti-CEA CAR was expressed for comparison. C: Culture supernatants of $\mathbf{D}$ were recorded for IFN- $\gamma$ to monitor activation of redirected T cells. Data represent the means \pm SEM of triplicates; one representative experiment of five is shown. D: Cytolysis of RMS cell lines by fAChR-redirected $T$ cells engineered with the $\mathrm{CD} 3 \zeta$ and $\mathrm{CD} 28-\mathrm{CD} 3 \zeta$ CAR, respectively. Increasing numbers of CAR-modified T cells were co-incubated for 48 hours with RMS cells $\left(1 \times 10^{4}\right.$ cells per well). Survival of RMS cells was recorded as described in Materials and Methods. Survival of RMS cells in the presence of $T$ cells without CAR was set at $100 \%$. The fAChR-negative HEK and HeLa cells were used as controls. of two RMS samples confirmed overexpression of survivin and XIAP (Figure 3D). The results of fresh-frozen biopsy specimens were confirmed by immunohistochemical (IHC) analysis of 10 formalin-fixed, paraffin-embedded biopsy specimens (Figure 3F). Survivin expression levels were similar in tumor biopsy specimens of alveolar and embryonal RMS samples of metastatic (stage IV) and nonmetastatic (stage I to III) disease. Taking all analyzed 23 patients with RMS together (Table 1), irrespective of tumor stage, patients with higher survivin expression levels in tumor biopsy specimens showed predominantly poorer survival $(P=0.06)$ (Supplemental Figure S2). Tumor localization has prognostic impact ${ }^{27}$; although the sample number was too small for statistical analyses, there was a trend for higher survival rates correlating with lower survivin levels in the subgroup of RMS from other sites, which are, for instance, parameningeal tissue, bladder and prostate, genitourinary tract without bladder, and prostate (Supplemental Figure S2).

\section{Survivin Knockdown Improves Sensitivity of RMS Cells toward T-Cell-Mediated Killing}

To investigate the impact of survivin overexpression on the susceptibility of RMS cell lines toward T-cell-mediated killing, we knocked down survivin expression by specific 
A

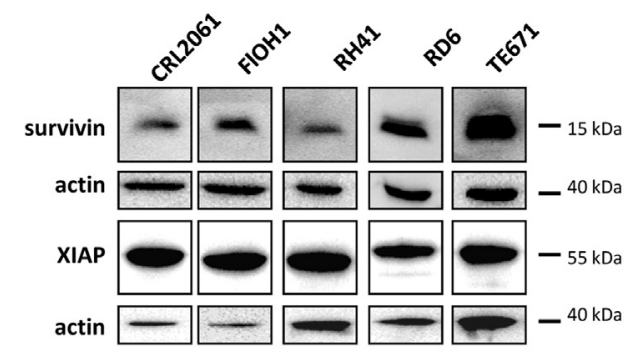

B

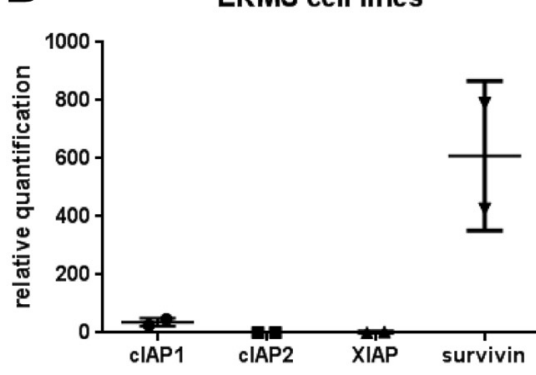

C

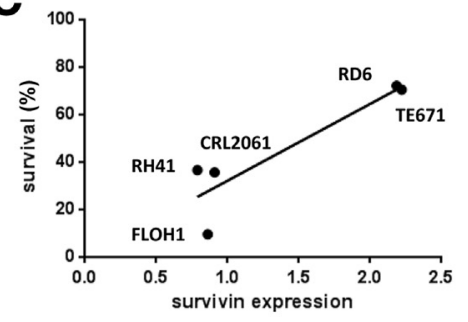

E

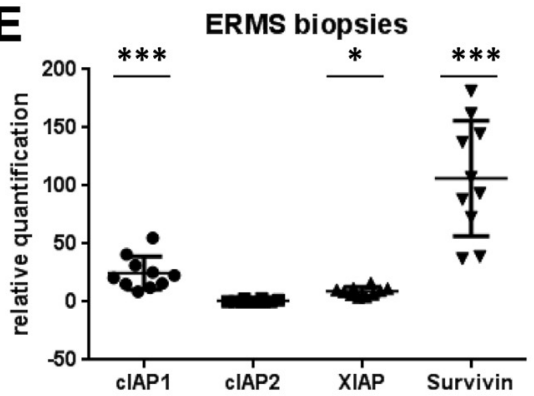

$\mathbf{F}$

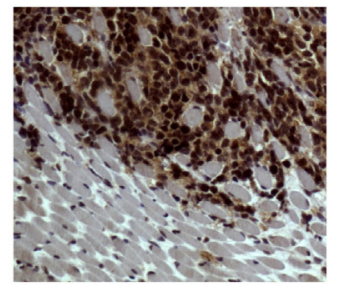

XIAP
ARMS cell lines

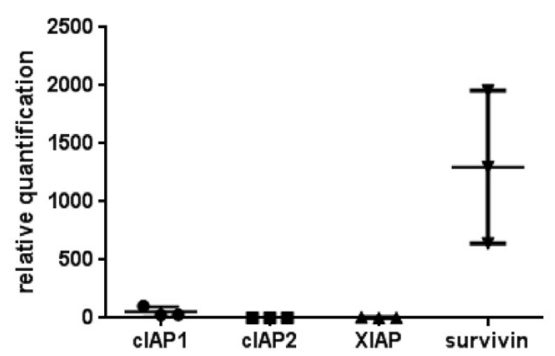

D
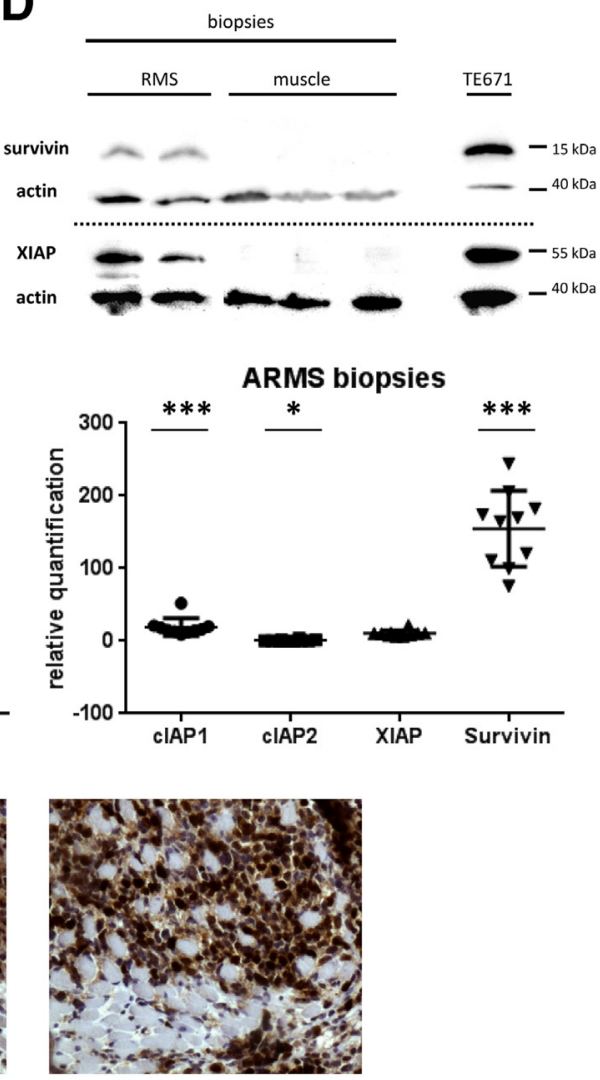

survivin
Figure 3 The RMS cells overexpress IAP molecules. A: Survivin and XIAP in lysates of RMS cells were detected by using Western blot analysis. Reprobing with an actin-specific antibody was used as a loading control. B: Relative expression of survivin, XIAP, CIAP1, and CIAP2 mRNA in RMS cells was determined by RT-qPCR, normalized to GAPDH-specific signals, and compared with healthy muscle cells. Expression of each of the respective IAPs in adult, innervated muscle was set as 1.0. RQ, relative quotient. Data represent the means \pm SEM. Statistical analysis was performed using REST. C: T-cell-mediated cytotoxicity correlates with survivin expression levels in RMS cell lines. Cytotoxicity data from Figure 2 were plotted against survivin expression levels (A). R, regression coefficient was calculated using Pearson's correlation. D: Survivin and XIAP expression was recorded by using Western blot analysis in patient RMS biopsy specimens $(n=2)$. Biopsy specimens from adult muscle served as controls $(n=3)$. Actin was recorded as loading control. Lysates of TE671 RMS cells served as additional control. E: Expression of survivin, XIAP, cIAP1, and cIAP2 mRNA in embryonal $(n=10)$ and alveolar $(n=10)$ RMS biopsy specimens, as determined by qPCR and normalized to GAPDH signals. For comparison, expression of the respective IAPs in healthy, innervated muscle was set as 1.0. F: The IHC detection of survivin and XIAP in RMS biopsy specimens. The case shown is representative for the two alveolar and eight embryonal RMS biopsy specimens analyzed in this study. Survivin and XIAP are strongly expressed in RMS infiltrates (dark brown), with no detectable expression in the adjacent healthy muscle. Cells were stained with the DAKO EnVision G/2 Doublestain System, Rabbit/Mouse using 3,3'diaminobenzidine (DAB) as chromogen. Original magnification, $\times 200$. ${ }^{*} P<0.05,{ }^{* * *} P<0.001$.
siRNAs in RD6, TE671, FLOH1, and RH41 cells. siRNA treatment reduced survivin mRNA (data not shown) and protein expression compared with control treatment with scrambled siRNA or without siRNA; exemplary data are shown in Figure 4A. Expression of the fAChR was only marginally altered in survivin-specific siRNA-treated cells (data not shown). RMS cells with repressed survivin showed increased susceptibility to the fAChR-redirected T-cell attack compared with non-treated RMS cells (Figure 4A). This was particularly evident in the cell lines, RD6 and TE671, with highest survivin expression in which sensitivity to cytolysis increased from background levels to approximately $40 \%$ and $60 \%$, respectively. Addition of the cyclooxygenase- 2 inhibitor, celecoxib, to RMS cells decreased survivin expression to 

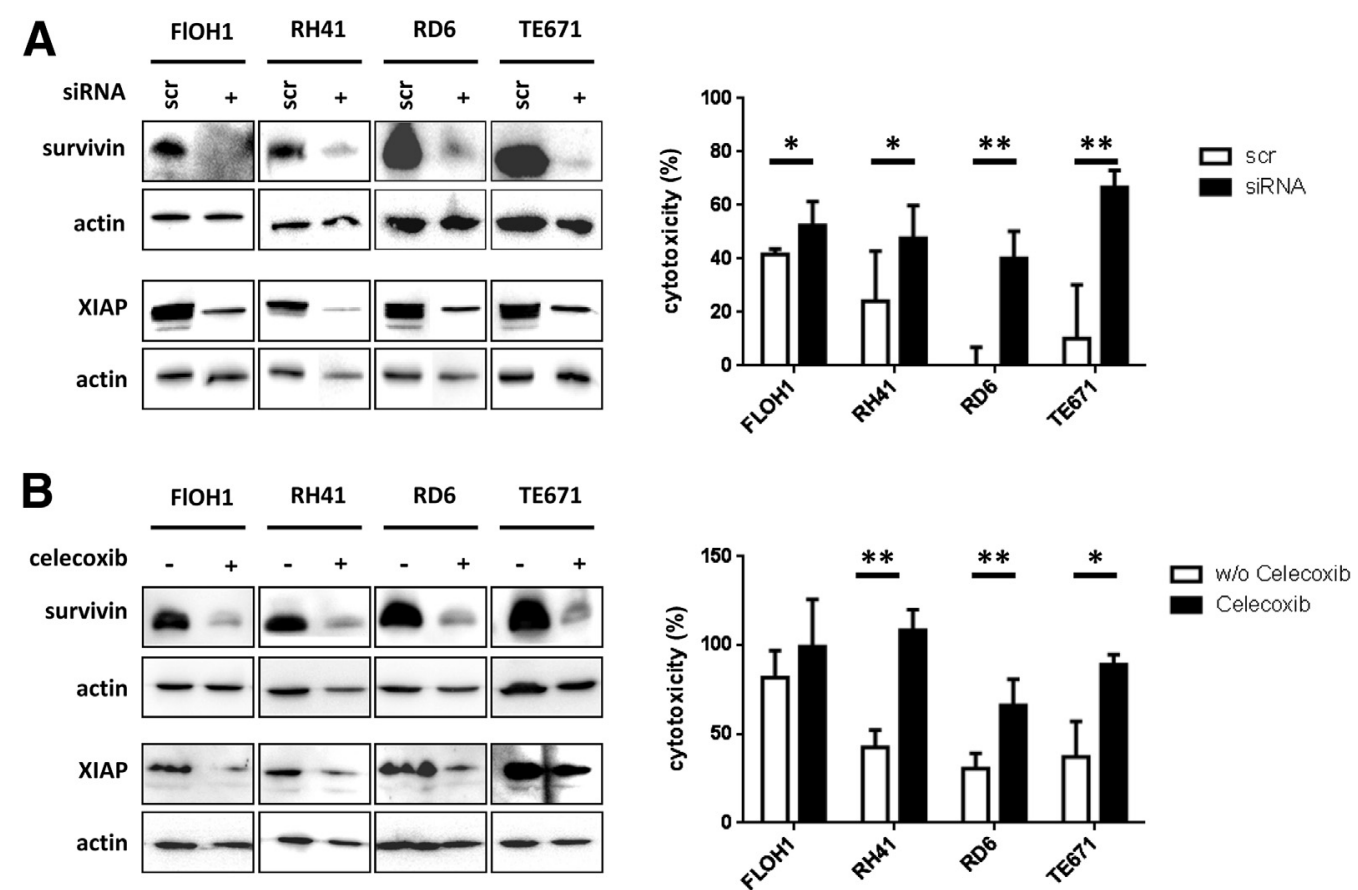

Figure 4 Survivin knockdown by either siRNA or celecoxib sensitizes RMS cells for a redirected T-cell attack. A: The RMS cells were treated with survivinspecific siRNA or scrambled (src) siRNA, as described in Materials and Methods. Survivin and XIAP expression were recorded by using Western blot analysis. Reprobing with actin antibody served as a loading control. Cells of RMS lines $\left(1 \times 10^{4}\right.$ cells per well) were co-incubated with CD28-CD3 $\zeta$ CAR-redirected T cells $\left(1.25 \times 10^{4}\right.$ cells per well) after siRNA-mediated survivin knockdown or after treatment with src siRNA. Survival of RMS cells in the presence of unmodified T cells was set at 100\%. B: Cells of RMS lines FLOH1, RH41, RD6, and TE671 were treated with $60 \mu \mathrm{mol} / \mathrm{L}$ celecoxib for 72 hours, and expression levels of survivin and XIAP were recorded by using Western blot analysis. Treatment with dimethyl sulfoxide (DMSO) without celecoxib served as a control. A total of $1 \times 10^{4}$ cells per well of RMS cells treated with or without celecoxib were co-incubated with $2.5 \times 10^{4}$ cells per well of CD28-CD3 $\zeta$ CAR-redirected T cells for 48 hours, and RMS cell survival was determined. Survival of RMS cells on co-incubation with unmodified T cells was set at $100 \%$. Data represent the means of triplicates + SEM; one representative experiment of three is shown. Statistical analysis was performed using the Student's $t$-test. ${ }^{\star} P<0.05$, $* * P<0.01$.

$40 \%$ to $60 \%$ in vitro (Figure 4B). Pretreatment with celecoxib by 1.2 - to 2.5 -fold increased sensitivity of RMS cells toward cytolysis by fAChR-redirected $\mathrm{T}$ cells compared with mocktreated RMS cells (Figure 4B).

\section{In Vivo Mouse Experiments}

To evaluate the influence of survivin on the killing of RMS cells by fAChR-specific T cells in vivo, we chose the highly resistant ERMS cell line, RD6, that we previously showed to express the highest levels of survivin among the tested RMS cell lines (Figure 3C). RD6-bearing immunodeficient $\mathrm{Rag}^{-/-}$mice were treated with single injections of fAChRspecific chimeric $\mathrm{T}$ cells, using injection of non-transduced $\mathrm{T}$ cells as control. fAChR-specific, but not control, $\mathrm{T}$ cells delayed the growth of xenotransplants. However, tumor eradication was not achieved (Figure 5A).

To evaluate whether pretreatment with a survivin inhibitor enhances the therapeutic efficacy of chimeric $\mathrm{T}$ cells, we pre-treated the mice by i.v. injection with SHP that interferes with the survivin-Hsp90 interaction, resulting in survivin degradation. ${ }^{28}$ When the RD6 xenotransplant tumor was established, mice received SHP from day -7 until day 7 of a single T-cell administration. Control mice received only SHP. T cells were engineered with an fAChR-specific CAR or without CAR. SHP decelerated tumor growth during T-cell treatment (Figure 5B). SHP administration is required because tumor growth accelerated when SHP treatment was discontinued.

\section{Discussion}

Patients with primary resistant, metastatic, or recurrent RMS have a poor prognosis, raising the need for innovative treatment strategies. Immune therapy may offer such an approach because RMS cells are potentially susceptible to cytolysis by redirected $\mathrm{T}$ cells, ${ }^{14}$ antigen-independent cytokine-induced killer cells, ${ }^{29}$ and activated natural killer cells, ${ }^{30}$ although with disappointing low efficacy. Herein, we show that this may be due to, at least in part, inefficient effector cell activation as the result of lack of costimulation. Absence of costimulatory CD80 and CD86, previously described as a shared feature of TE671 embryonal RMS cells and normal muscle, ${ }^{31}$ is shown to be a more general property of alveolar and embryonal RMS cell lines $(n=5)$ and RMS in vivo $(n=23)$. In addition, ICOS-L expression was found to be augmented by $\mathrm{TNF} \alpha$, which has potential relevance for vaccination strategies in patients with RMS. 


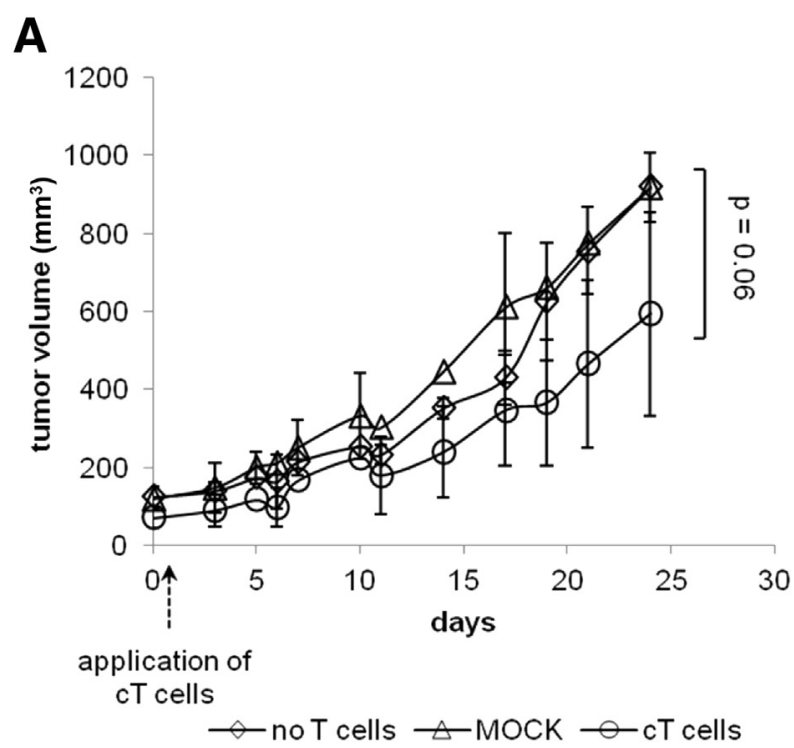

B

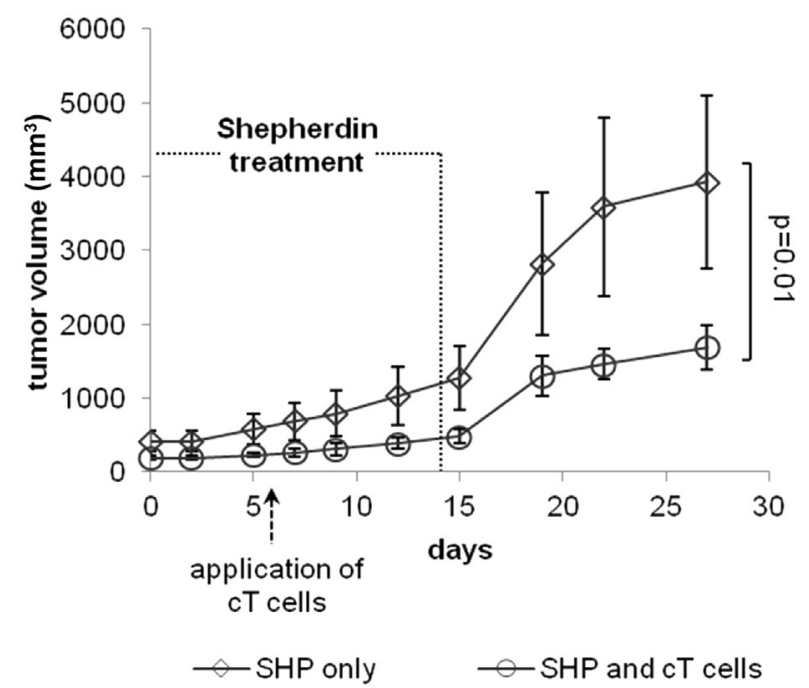

Figure 5 In vivo treatment of RMS-bearing $\mathrm{Rag}^{-/-}$mice with fAChRspecific chimeric T cells. A: RMS (RD6)-bearing $\mathrm{Rag}^{-1-}$ mice $(n=4)$ were treated once i.v. with either $1 \times 10^{7}$ second-generation chimeric $T$ cells or non-transduced $T$ cells as controls. Tumor growth was determined with the aid of a caliper rule for 21 days. B: To inhibit survivin expression of RD6 tumor cells, tumor-bearing mice $(n=4)$ were treated with $50 \mathrm{mg} / \mathrm{kg}$ SHP (resolved in PBS), which was given i.p. every 2 days. Treatment was started 7 days before T-cell application and was performed for 14 days after T-cell application. Data represent the means \pm SEM of four treated mice. Statistical analysis was performed using the Student's $t$-test.

Because RMS cells do not express costimulatory molecules, such as CD80 and CD86, we took advantage of a second-generation CAR with a combined CD28-CD3 $\zeta$ signaling domain, which provides $\mathrm{CD} 28$ costimulation in the absence of physiological CD28-CD80 interaction. T-cell activation toward RMS cells was substantially improved through $\mathrm{CD} 28-\mathrm{CD} 3 \zeta$ CAR signaling, as indicated by stronger secretion of IFN- $\gamma$ compared with T cells with CD3 $\zeta$ CAR. Despite full T-cell activation, RMS cell lysis was poor, implying that RMS cell-intrinsic factors contribute to therapy resistance.

Several anti-apoptotic mechanisms were previously detected in RMS cells, ${ }^{2,32}$ including overexpression of survivin, ${ }^{33,34}$ XIAP, cIAP1, and cIAP $2,{ }^{35}$ and members of the Bcl-2 family. ${ }^{35-39}$ Accordingly, we found members of the IAP family deregulated in the analyzed RMS cells. Survivin, in particular, is strongly overexpressed in both alveolar and embryonal RMS cell lines and, moreover, in RMS biopsy specimens. Blocking survivin expression reduces proliferation and viability of RMS xenotransplants, ${ }^{33,38}$ increases radiosensitivity through interference with DNA repair, ${ }^{40}$ and protects XIAP against ubiquitination ${ }^{41}$ and proteasomal degradation. ${ }^{42}$ We, therefore, asked whether down-regulation of survivin makes RMS cells more sensitive to a cytotoxic T-cell attack.

Survivin repression by siRNA or celecoxib, a clinically approved cyclooxygenase-2 inhibitor that represses survivin expression in RMS cells ${ }^{43}$ and interferes with survivin protein stability, ${ }^{44}$ rendered resistant RMS cell lines more susceptible to T-cell-mediated lysis. Celecoxib reduced survivin expression in all RMS cell lines tested, and all RMS cell lines were sensitized toward redirected $\mathrm{T}$ cells, indicating the general relevance of the effect.

Because survivin stabilizes XIAP, as reported for breast cancer cells, ${ }^{42}$ survivin down-regulation by celecoxib was paralleled by the reduction of XIAP levels, although at variable degrees. Combined targeting of XIAP and survivin is, therefore, expected to also result in improved sensitization of RMS cells toward T-cell-mediated apoptosis. As known for other cancer entities, XIAP overexpression in RMS cells is likely to have additional impact on the outcome of therapeutic strategies exploiting extrinsic, tumor necrosis factor-related apoptosis-inducing ligand treatment-mediated, or intrinsic, smac-induced apoptosis pathways. ${ }^{45}$ The relevance of XIAP for the execution of a T-cell attack is sustained by our previous observation that XIAPoverexpressing Hodgkin lymphoma cells were rendered susceptible to redirected T cells by XIAP knockdown. ${ }^{46}$

In vivo analysis, using a xenograft transplant model, confirmed the relevance of survivin expression for RMS tumor cell survival and growth. Because celecoxib is associated with severe adverse effects, we used the welltolerated survivin inhibitor, SHP. SHP reduces growth of prostate and breast cancer cells in vitro and in vivo by interfering with the Hsp90-survivin interaction. ${ }^{28}$ T-cell therapy, together with SHP treatment, more effectively repressed tumor progression than T-cell therapy alone. The impact of SHP was underlined by the fact that after the end of SHP treatment, the tumor progressed more rapidly in both situations whether or not mice had received fAChR-specific chimeric T cells.

We used the ERMS cell line, RD6, in the xenotransplant study because these cells were most resistant to T-cell lysis in vitro; however, the observations have some limitations. First, considering the different sensitivity of ERMS and ARMS cells toward fAChR-directed chimeric $\mathrm{T}$ cells 
in vitro and their different biological characteristics in patients, it will be of interest to record their response in vivo on T-cell therapy. Second, SHP specifically mimics the Hsp90-interacting region of $\operatorname{survivin}^{28}$; however, it can formally not be excluded that unintended blockade of other client proteins may also contribute to the repressive effect of SHP on the progression of RMS xenotransplants. Inducible shRNA-mediated survivin knockdown will help to confirm the role of survivin in T-cell-mediated killing of RMS cells in vivo.

Selection of fAChR low-expressor RMS subclones during treatment with fAChR-redirected chimeric $\mathrm{T}$ cells could result in the failure to completely eradicate RMS xenografts. This possibility has also been proposed to explain the recurrence of RMS xenotransplants after cessation of an immunotoxin-based therapy directed against the $\mathrm{fAChR}^{47}$ (Figure 5A).

Targeting of survivin in RMS cells and their sensitization toward a T-cell attack can be translated into clinical practice using small molecules (eg, YM155) ${ }^{48-50}$ which suppress survivin and which are explored in phase 1 therapy of solid tumors and lymphomas. Anti-sense oligonucleotides against survivin accumulated in tumor tissue accompanied by down-regulated survivin mRNA and protein expression and repressed tumor cell proliferation. ${ }^{50}$ Patients with RMS treated by adoptive immunotherapy are, therefore, expected to benefit from blocking survivin by siRNA or celecoxib.

Finally, the current findings have relevance for vaccination-based strategies in the treatment of RMS due to common cytotoxic effector mechanisms. Considering the negative correlation between the survivin levels in RMS, the survival time of patients with RMS, and the sensitivity to cytotoxic $\mathrm{T}$ cells, survivin is a candidate biomarker for predicting efficacy in cellular immunotherapy. Furthermore, the induction of ICOS-L in a subset of RMS cell lines is of particular interest to improve therapeutic efficacy because ICOS-L-mediated costimulation is crucial for specific $\mathrm{T}$ cells to effectively lyse non-RMS tumor cells ${ }^{7,8}$ and to destruct inflamed human skeletal muscle in vivo. ${ }^{31}$

\section{Acknowledgments}

We thank Andrea Homburger for expert IHC staining and Nicole Hoffmann for support in performing mouse experiments.

\section{Supplemental Data}

Supplemental material for this article can be found at http://dx.doi.org/10.1016/j.ajpath.2013.02.017.

\section{References}

1. Dantonello TM, Int-Veen C, Harms D, Leuschner I, Schmidt BF, Herbst M, Juergens H, Scheel-Walter HG, Bielack SS, Klingebiel T, Dickerhoff R, Kirsch S, Brecht I, Schmelzle R, Greulich M,
Gadner H, Greiner J, Marky I, Treuner J, Koscielniak E: Cooperative trial CWS-91 for localized soft tissue sarcoma in children, adolescents, and young adults. J Clin Oncol 2009, 27:1446-1455

2. Wachtel M, Schäfer BW: Targets for cancer therapy in childhood sarcomas. Cancer Treat Rev 2010, 36:318-327

3. Mackall CL, Rhee EH, Read EJ, Khuu HM, Leitman SF, Bernstein D, Tesso M, Long LM, Grindler D, Merino M, Kopp W, Tsokos M, Berzofsky JA, Helman LJ: A pilot study of consolidative immunotherapy in patients with high-risk pediatric sarcomas. Clin Cancer Res 2008, 14:4850-4858

4. Hashii Y, Sato E, Ohta H, Oka Y, Sugiyama H, Ozono K: WT1 peptide immunotherapy for cancer in children and young adults. Pediatr Blood Cancer 2010, 55:352-355

5. Eshhar Z: The T-body approach: redirecting $\mathrm{T}$ cells with antibody specificity. Edited by Chernajovsky Y, Nissim A. Therapeutic Antibodies. Springer Berlin Heidelberg, 2008, pp 329-342

6. Mellman I, Coukos G, Dranoff G: Cancer immunotherapy comes of age. Nature 2011, 480:480-489

7. Zuberek K, Ling V, Wu P, Ma HL, Leonard JP, Collins M, DunussiJoannopoulos K: Comparable in vivo efficacy of CD28/B7, ICOS/GL50, and ICOS/GL50B costimulatory pathways in murine tumor models: IFN $\gamma$-dependent enhancement of CTL priming, effector functions, and tumor specific memory CTL. Cell Immunol 2003, 225:53-63

8. Liu X, Bai XF, Wen J, Gao JX, Liu J, Lu P, Wang Y, Zheng P, Liu Y: $\mathrm{B} 7 \mathrm{H}$ costimulates clonal expansion of, and cognate destruction of tumor cells by, $\mathrm{CD}(8)+\mathrm{T}$ lymphocytes in vivo. J Exp Med 2001, 194:1339-1348

9. Krummel MF, Heath WR, Allison J: Differential coupling of second signals for cytotoxicity and proliferation in CD8 $+\mathrm{T}$ cell effectors: amplification of the lytic potential by B7. J Immunol 1999, 163: 2999-3006

10. Chmielewski M, Hombach AA, Abken H: CD28 cosignalling does not affect the activation threshold in a chimeric antigen receptorredirected T-cell attack. Gene Ther 2011, 18:62-72

11. Hombach A, Wieczarkowiecz A, Marquardt T, Heuser C, Usai L, Pohl C, Seliger B, Abken H: Tumor-specific T cell activation by recombinant immunoreceptors: CD3 zeta signaling and CD28 costimulation are simultaneously required for efficient IL-2 secretion and can be integrated into one combined CD28/CD3 zeta signaling receptor molecule. J Immunol 2001, 167:6123-6131

12. Kochenderfer JN, Dudley ME, Feldman SA, Wilson WH, Spaner DE, Maric I, Stetler-Stevenson M, Phan GQ, Hughes MS, Sherry RM, Yang JC, Kammula US, Devillier L, Carpenter R, Nathan DA, Morgan RA, Laurencot C, Rosenberg SA: B-cell depletion and remissions of malignancy along with cytokine-associated toxicity in a clinical trial of anti-CD19 chimeric-antigen-receptor-transduced T cells. Blood 2012, 119:2709-2720

13. Gattenloehner S, Vincent A, Leuschner I, Tzartos S, MullerHermelink H, Kirchner T, Marx A: The fetal form of the acetylcholine receptor distinguishes rhabdomyosarcomas from other childhood tumors. Am J Pathol 1998, 152:437-444

14. Gattenlöhner S, Marx A, Markfort B, Pscherer S, Landmeier S, Juergens H, Müller-Hermelink HK, Matthews I, Beeson D, Vincent A, Rossig C: Rhabdomyosarcoma lysis by T cells expressing a human autoantibody-based chimeric receptor targeting the fetal acetylcholine receptor. Cancer Res 2006, 66:24-28

15. Gattenlöhner S, Müller-Hermelink H-K, Marx A: Polymerase chain reaction-based diagnosis of rhabdomyosarcomas: comparison of fetal type acetylcholine receptor subunits and myogenin. Diagn Mol Pathol 1998, 7:129-134

16. Gattenloehner S, Dockhorn-Dworniczak B, Leuschner I, Vincent A, Müller-Hermelink H, Marx A: A comparison of MyoD1 and fetal acetylcholine receptor expression in childhood tumors and normal tissues implications for the molecular diagnosis of minimal disease in rhabdomyosarcomas. J Mol Diagn 1999, 1: $23-31$ 
17. Simon-Keller K, Barth S, Vincent A, Marx A: Targeting the fetal acetylcholine receptor in rhabdomyosarcoma. Expert Opin Ther Targets 2013, 17:127-138

18. Kashkar H, Seeger J-M, Hombach A, Deggerich A, Yazdanpanah B, Utermohlen O, Heimlich G, Abken H, Kronke M: XIAP targeting sensitizes Hodgkin lymphoma cells for cytolytic T-cell attack. Blood 2006, 108:3434-3440

19. Seeger JM, Schmidt P, Brinkmann K, Hombach AA, Coutelle O, Zigrino P, Wagner-Stippich D, Mauch C, Abken H, Krönke M, Kashkar H: The proteasome inhibitor bortezomib sensitizes melanoma cells toward adoptive CTL attack. Cancer Res 2010, 70: $1825-1834$

20. Hu D, Liu S, Shi L, Li C, Wu L, Fan Z: Cleavage of survivin by Ganzyme M triggers degradation of the survivin-X-linked inhibitor of apoptosis protein (XIAP) complex to free caspase activity leading to cytolysis of target tumor cells. J Biol Chem 2010, 285:18326-18335

21. Altieri D: Survivin and IAP proteins in cell-death mechanisms. Biochem J 2010, 430:199-205

22. Hombach A, Schneider C, Sent D, Koch D, Willemsen RA, Diehl V, Kruis W, Bolhuis RL, Pohl C, Abken H: An entirely humanized CD3 $\zeta$-chain signaling receptor that directs peripheral blood t cells to specific lysis of carcinoembryonic antigen-positive tumor cells. Int Cancer 2000, 88:115-120

23. Dantonello TM, Int-Veen C, Winkler P, Leuschner I, Schuck A, Schmidt BF, Lochbuehler H, Kirsch S, Hallmen E, Veit-Friedrich I, Bielack SS, Niggli F, Kazanowska B, Ladenstein R, Wiebe T, Klingebiel T, Treuner J, Koscielniak E: Initial patient characteristics can predict pattern and risk of relapse in localized rhabdomyosarcoma. J Clin Oncol 2008, 26:406-413

24. Stegmaier S, Poremba C, Schaefer K-L, Leuschner I, Kazanowska B, Békássy AN, Bielack SS, Klingebiel T, Koscielniak E: Prognostic value of PAX-FKHR fusion status in alveolar rhabdomyosarcoma: a report from the cooperative soft tissue sarcoma study group (CWS). Pediatr Blood Cancer 2011, 57:406-414

25. Stratton MR, Reeves BR, Cooper CS: Misidentified cell. Nature 1989, 337:311-312

26. Hombach A, Heuser C, Abken H: Generation, expression, and monitoring of recombinant immune receptors for use in cellular immunotherapy. Methods Mol Biol 2003, 207:365-381

27. Carli M, Colombatti R, Oberlin O, Bisogno G, Treuner J, Koscielniak E, Tridello G, Garaventa A, Pinkerton R, Stevens M: European intergroup studies (MMT4-89 and MMT4-91) on childhood metastatic rhabdomyosarcoma: final results and analysis of prognostic factors. J Clin Oncol 2004, 22:4787-4794

28. Plescia J, Salz W, Xia F, Pennati M, Zaffaroni N, Daidone MG, Meli M, Dohi T, Fortugno P, Nefedova Y, Gabrilovich DI, Colombo G, Altieri DC: Rational design of shepherdin, a novel anticancer agent. Cancer Cell 2005, 7:457-468

29. Kuçi S, Rettinger E, Voss B, Weber G, Stais M, Kreyenberg H, Willasch A, Kuçi Z, Koscielniak E, Klöss S, von Laer D, Klingebiel T, Bader P: Efficient lysis of rhabdomyosarcoma cells by cytokine-induced killer cells: implications for adoptive immunotherapy after allogeneic stem cell transplantation. Haematologica 2010, 95:1579-1586

30. Cho D, Shook DR, Shimasaki N, Chang YH, Fujisaki H, Campana D: Cytotoxicity of activated natural killer cells against pediatric solid tumors. Clin Cancer Res 2010, 16:3901-3909

31. Wiendl H, Mitsdoerffer M, Schneider D, Melms A, Lochmuller H, Hohlfeld R, Weller M: Muscle fibres and cultured muscle cells express the B7.1/2 related inducible co-stimulatory molecule, ICOSL: implications for the pathogenesis of inflammatory myopathies. Brain 2003, 126:1026-1035

32. Fulda S: Exploiting apoptosis pathways for the treatment of pediatric cancers. Pediatr Blood Cancer 2009, 53:533-536

33. Caldas H, Holloway M, Hall B, Qualman S, Altura R: Survivindirected RNA interference cocktail is a potent suppressor of tumour growth in vivo. J Med Genet 2006, 43:119-128
34. Singh S, Vinson C, Gurley CM, Nolen GT, Beggs ML, Nagarajan R, Wagner EF, Parham DM, Peterson CA: Impaired Wnt signaling in embryonal rhabdomyosarcoma cells from p53/c-fos double mutant mice. Am J Pathol 2010, 177:2055-2066

35. Izeradjene K, Douglas L, Delaney AB, Houghton JA: Casein kinase I attenuates tumor necrosis factor-related apoptosis-inducing ligand-induced apoptosis by regulating the recruitment of fasassociated death domain and procaspase- 8 to the death-inducing signaling complex. Cancer Res 2004, 64:8036-8044

36. Margue C, Bernasconi M, Barr F, Schäfer B: Transcriptional modulation of the anti-apoptotic protein BCL-XL by the paired box transcription factors PAX3 and PAX3/FKHR. Oncogene 2000, 19:2921-2929

37. Mayeenuddin LH, Yu Y, Kang Z, Helman LJ, Cao L: Insulin-like growth factor 1 receptor antibody induces rhabdomyosarcoma cell death via a process involving AKT and Bcl-x(L). Oncogene 2010, 29: 6367-6377

38. Wei C, Ball S, Lin L, Liu A, Fuchs J, Li P, Li C, Lin J: Two small molecule compounds, LLL12 and FLLL32, exhibit potent inhibitory activity on STAT3 in human rhabdomyosarcoma cells. Int J Oncol 2011, 38:279-285

39. Zhou H, Shen T, Luo Y, Liu L, Chen W, Xu B, Han X, Pang J, Rivera C, Huang S: The antitumor activity of the fungicide ciclopirox. Int J Cancer 2010, 127:2467-2477

40. Rödel F, Reichert S, Sprenger T, Gaipl US, Mirsch J, Liersch T, Fulda S, Rödel C: The role of survivin for radiation oncology: moving beyond apoptosis inhibition. Curr Med Chem 2011, 18:191-199

41. Carrasco RA, Stamm NB, Marcusson E, Sandusky G, Iversen P, Patel BK: Antisense inhibition of survivin expression as a cancer therapeutic. Mol Cancer Ther 2011, 10:221-232

42. Dohi T, Okada K, Xia F, Wilford CE, Samuel T, Welsh K, Marusawa H, Zou H, Armstrong R, Matsuzawa S, Salvesen GS, Reed JC, Altieri DC: An IAP-IAP complex inhibits apoptosis. J Biol Chem 2004, 279:34087-34090

43. Reed S, Li H, Li C, Lin J: Celecoxib inhibits STAT3 phosphorylation and suppresses cell migration and colony forming ability in rhabdomyosarcoma cells. Biochem Biophys Res Commun 2011, 407:450-455

44. Krysan K, Merchant FH, Zhu L, Dohadwala M, Luo J, Lin Y, HeuzeVourc'h N, Põld M, Seligson D, Chia D, Goodglick L, Wang H, Strieter R, Sharma S, Dubinett S: COX-2-dependent stabilization of survivin in non-small cell lung cancer. FASEB J 2004, 18:206-208

45. Galban S, Duckett CS: XIAP as a ubiquitin ligase in cellular signaling. Cell Death Differ 2009, 17:54-60

46. Kashkar H, Deggerich A, Seeger J-M, Yazdanpanah B, Wiegmann K, Haubert D, Pongratz C, Kronke M: NF-\{kappa\}B-independent downregulation of XIAP by bortezomib sensitizes HL B cells against cytotoxic drugs. Blood 2007, 109:3982-3988

47. Gattenlöhner S, Jörissen H, Huhn M, Vincent A, Beeson D, Tzartos S, Mamalaki A, Etschmann B, Muller-Hermelink HK, Koscielniak E, Barth S, Marx A: A human recombinant autoantibodybased immunotoxin specific for the fetal acetylcholine receptor inhibits rhabdomyosarcoma growth in vitro and in a murine transplantation model. J Biomed Biotechnol 2010, 2010:187621

48. Tanioka M, Nokihara H, Yamamoto N, Yamada Y, Yamada K, Goto Y, Fujimoto T, Sekiguchi R, Uenaka K, Callies S, Tamura T: Phase I study of LY2181308, an antisense oligonucleotide against survivin, in patients with advanced solid tumors. Cancer Chemother Pharmacol 2011, 68:505-511

49. Tolcher AW, Mita A, Lewis L, Garrett CR, Till E, Daud AI, Patnaik A, Papadopoulos K, Takimoto C, Bartels P, Keating A, Antonia S: Phase I and pharmacokinetic study of YM155, a smallmolecule inhibitor of survivin. J Clin Oncol 2008, 26:5198-5203

50. Talbot DC, Ranson M, Davies J, Lahn M, Callies S, André V, Kadam S, Burgess M, Slapak C, Olsen AL, McHugh PJ, de Bono JS, Matthews J, Saleem A, Price P: Tumor survivin is downregulated by the antisense oligonucleotide LY2181308: a proof-of-concept, first-in-human dose Study. Clinical Cancer Res 2010, 16:6150-6158 